\title{
Artikel
}

\section{Ruimtelijk beleid voor de energietransitie: centraal wat moet?}

\author{
Een studie naar het omgevingsrechtelijk overheidsinstrumentarium in de energietransitie
}

\section{Mr. A.M.J.R. (Fons) van der Linden en mr. drs. S. (Sanne) Akerboom*}

\section{De (de)centrale energietransitie}

Met het ondertekenen van het Klimaatakkoord van Parijs in december 2015 heeft Nederland zich verbonden aan de internationale doelstelling om de temperatuurstijging als gevolg van broeikasgassenuitstoot tot 2 graden Celsius, maar het liefst tot $1,5 \operatorname{graad}$ Celsius te beperken. Deze doelstelling is in de Energieagenda vertaald naar een $\mathrm{CO}_{2}$-reductiedoelstelling van $80-95 \%$ in $2050 .{ }^{1}$ In het regeerakkoord is daarnaast een nationale reductiedoelstelling opgenomen van $49 \%$ in 2030 ten opzichte van 1990. De opgave om $\mathrm{CO}_{2}$-emissies terug te dringen impliceert grote veranderingen in de Nederlandse energievoorziening. Deze is immers verantwoor- delijk voor een groot aandeel van deze uitstoot - ongeveer $80 \%{ }^{2}$

Naast reductiedoelstellingen spelen andere motivaties en doelstellingen een rol in de energietransitie. Zo leidt onder meer het recente besluit om de aardgaswinning in Groningen uiterlijk in 2030 stop te zetten ${ }^{3}$ tot de vraag hoe de nationale warmtebehoefte - die momenteel nog voor ongeveer $90 \%$ wordt ingevuld met aardgas - op een alternatieve, duurzame wijze kan worden ingevuld. Daarnaast zijn er doelstellingen met betrekking tot het aandeel energie dat duurzaam moet worden opgewekt: $14 \%$ in 2020 en $16 \%$ in $2023 .{ }^{4}$ Een deel daarvan wordt gerealiseerd door het opgestelde vermogen windenergie op land en op zee te verhogen. Daarbij wordt ingezet op minimaal $17.450 \mathrm{MW}$ per $2030,{ }^{5}$ zowel op land als op zee met windparken van $350 \mathrm{MW}$ of meer. ${ }^{6}$

Vanwege het belang voor het behalen van rijksdoelstellingen voor duurzame energie is de doorzettingsmacht van de provincies ten aanzien van windenergie met de Crisis- en herstelwet (Chw) aanzienlijk versterkt. ${ }^{7}$ Naar geleerdheid van de Universiteit van Amsterdam binnen het project 'Institutionele en regulatorische innovatie ten behoeve van lokale, slimme energievoorzieningen (IRIS)' en tevens verbonden aan het Centrum voor Energievraagstukken bij de Faculteit Recht, Economie, Bestuurs- en Organisatiekunde van de Universiteit Utrecht. Mr. drs. S. Akerboom is postdoc bij het Utrecht Centre for Water, Oceans and Sustainability Law en het Centrum voor Energievraagstukken bij de Faculteit Recht, Economie, Bestuurs- en Organisatiekunde van de Universiteit Utrecht, project 'Resilient Societies', in het bijzonder 'Sustainable Energy'.

1. Ministerie van Economische Zaken, Energieagenda: naar een $\mathrm{CO}_{2}$-arme energievoorziening, Den Haag: Ministerie van Economische Zaken, december 2016, p. 21.
2. Ministerie van Economische Zaken, Energierapport - Transitie naar duurzaam, Den Haag: Ministerie van Economische Zaken 2016, p. 24.

3. Kamerstukken II 2017/18, 33 592, nr. 457.

4. SER, Energieakkoord voor duurzame groei, 2013, p. 17.

Kamerstukken II 2017/18, 33 561, nr. A/11.

6. Het gaat om maximaal $6000 \mathrm{MW}$ windenergie op land, wat gerealiseerd moet zijn in 2020 en 4450 MW windenergie op zee in 2023. Tussen 2024 en 2030 zal minstens een additionele 7000 MW windelenergie op zee worden gerealiseerd. Brief van de minister van Economische Zaken en Klimaat aan de Tweede Kamer, Routekaart wind op zee 2030, 27 maart 2018.

7. Kamerstukken II 2009/10, 32 127, nr. 3, p. 22. 
aanleiding van het Energieakkoord $(2013)^{8}$ zijn vervolgens afspraken over windenergie tussen Rijk en provincies in ruimtelijk beleid en regelgeving neergelegd, waarbij het doel enerzijds is om het afgesproken vermogen windenergie voor 2020 te realiseren, maar anderzijds ook om 'verrommeling' van het landschap te voorkomen. Vaak komt dit neer op een verbod op het bouwen of vervangen van (solitaire) windturbines die niet binnen provinciaal beleid of regelgeving passen, waarmee de provincie de deur voor lokale initiatieven dichtgooit. Dit terwijl er lokale toepassingen denkbaar zijn waarbij windturbines prima in de fysieke leefomgeving passen, zoals bij bedrijventerreinen, op het erf van agrarische bedrijven, of als gemeenschappelijke turbine bij een kleine dorpskern (dorpsmolens). ${ }^{9}$ Voor windenergie is daarmee gekozen voor een grootschalige aanpak met een 'generieke' ruimtelijke afweging door de provincie, die dikwijls leidt tot conflicten met lagere overheden en burgers, bedrijven en belangengroepen die zich verzetten tegen 'provinciale' windturbineparken, of juist in het kader van lokale windenergieprojecten tegen belemmerende 'generieke' regels aanlopen. ${ }^{10}$

Waar beleid en regelgeving ten aanzien van windenergie zich al in een vergevorderd stadium bevinden, staat het beleid ten aanzien van de verduurzaming van de warmtevoorziening (hierna: warmtetransitie) nog in de kinderschoenen. Evenals bij elektriciteitsopwekking is er bij de warmtetransitie sprake van de mogelijkheid om te kiezen tussen grootschalige en kleinschalige oplossingen. Deze keuze is van meerdere factoren afhankelijk, zoals kenmerken van de gebouwde omgeving (bouwjaar, gebouwtype, bebouwingsdichtheid) en eventueel lokaal of regionaal aanwezige duurzame warmtebronnen, en is dus afhankelijk van de kansen en uitdagingen die de fysieke leefomgeving biedt.

Zowel voor windenergie als voor warmtetransitie geldt dat de keuze voor een bepaalde verduurzamingsmaatregel en schaalniveau in nauwe samenhang moet worden bezien met de ruimtelijke aspecten daarvan. Via het ruimtelijk instrumentarium kunnen de gekozen duurzaamheidspaden worden vastgelegd en gerealiseerd. Hiermee is een duidelijke connectie ontstaan tussen het energiebeleid en het omgevingsrecht. De vraag is wat het voor de ruimtelijke kwaliteit betekent als het omgevingsrecht ten dienste komt te staan voor het binnen een bepaalde termijn realiseren van specifieke energiedoelstellingen, zoals bij windenergie het geval is. Nog steeds wordt gesproken van het 'inpassen' van de energietran-

8. SER 2013.

9. D. Sijmons e.a., Energie en ruimte. Een nationaal perspectief, Rotterdam: Vereniging Deltametropool 2017, p. 104-105; Posad Spatial Strategies e.a., Ruimtelijke verkenning energie en klimaat, Den Haag: Posad Spatial Strategies 2018, p. 82-87.

10. Hoewel een regierol van de provincie met het oog op duurzaamheidsdoelstellingen zeker te rechtvaardigen is, is het de vraag in hoeverre de restricties die voor de lokale ruimtelijke afweging kunnen worden opgeworpen, zich verhouden met het uitgangspunt dat de ruimtelijke belangenafweging in beginsel plaatsvindt op het laagst mogelijke bestuursniveau. Zie par. 4.4. Zie ook ABRvS 30 augustus 2017, ECLI:NL:RVS: 2017:2331. sitie, terwijl - mede met het oog op de impact van de energietransitie op de ruimtelijke kwaliteit - op verschillende schaalniveaus moet worden gezocht naar integrale en creatieve oplossingen. Daarvoor is van belang dat de ruimtelijke afweging op lokaal niveau niet onevenredig wordt belemmerd.

In deze bijdrage wordt deze connectie tussen energietransitie en het omgevingsrecht nader onderzocht. Hierbij staat de vraag centraal hoe de keuze voor groot- of kleinschalige maatregelen het omgevingsrechtelijk kader en de ruimte voor een lokale ruimtelijke afweging kan beinvloeden. Daarbij zullen twee transitiepaden nader worden bekeken: windenergie op land (als onderdeel van het verduurzamen van de elektriciteitsproductie) en de verduurzaming van ruimteverwarming en warm tapwater in de gebouwde omgeving.

\section{Grootschalig of kleinschalig: ruimtelijke gevolgen en kansen van energie- infrastructuur}

De energietransitie betekent in de eerste plaats dat bestaande (fossiele) energiebronnen en bijbehorende technieken worden vervangen door innovatieve, hernieuwbare alternatieven. Technische vernieuwingen zullen zich voornamelijk richten op energiebesparing, efficiëntie en het opwekken van hernieuwbare energie. Er is een breed scala aan technieken voor duurzame en hernieuwbare energie die kunnen worden ingezet om een $\mathrm{CO}_{2}$-arme energievoorziening te realiseren. Zo kan elektriciteit worden opgewekt door middel van wind, zonlicht of stoom uit geothermie, kan biomassa worden vergist waarbij gas en warmte vrijkomen, en kan de warmtevraag deels worden ingevuld met restwarmte uit de industrie. Naar verwachting zal een groot deel van de technologieën die nu al bekend zijn een rol spelen in de energietransitie. $^{11}$

Nieuwe technieken voor hernieuwbare energie berusten in veel gevallen op andere concepten dan de oude, waardoor ook de infrastructuur, de organisatie en instituties eromheen en soms ook het gebruik ervan moeten worden aangepast. ${ }^{12} \mathrm{Er}$ is dus niet slechts sprake van fundamentele veranderingen op het gebied van de inrichting van de (fysieke) energievoorziening, maar ook op het gebied van gebruikspraktijken, de marktstructuur, juridische kaders en culturele opvattingen. ${ }^{13}$

11. Planbureau voor de Leefomgeving, Naar een schone economie in 2050: routes verkend. Hoe Nederland klimaatneutraal kan worden, Den Haag: Planbureau voor de Leefomgeving 2011, p. 84.

12. Planbureau voor de Leefomgeving, Balans van de leefomgeving 2016 , Den Haag: Planbureau voor de Leefomgeving 2016, p. 5.

13. A. Kern \& A. Smith, Restructuring Energy Systems for Sustainability? Energy Transition Policy in the Netherlands, Energy Policy 2008/36, p. 4094 
De energietransitie is dus geen simpele vervangingsopgave waarbij kolencentrales worden gesloten en worden vervangen door windturbines en zonnevelden, maar een proces waarbij keuzes moeten worden gemaakt, met steeds een andere ruimtelijke configuratie als gevolg. Ruimtelijke impact zal daarom een belangrijke rol spelen bij de keuze voor bepaalde transitiepaden, elk met eigen voordelen en beperkingen.

Grofweg is er sprake van twee 'beleidsdilemma's' tussen uitgangspunten van waaruit men kan nadenken over de balans tussen enerzijds energiedoelen en anderzijds andere ruimtelijke belangen. ${ }^{14}$ In de eerste plaats is er de keuze tussen grootschalige en kleinschalige maatregelen. Voorbeelden van grootschalige oplossingen zijn windparken op zee en op land en grootschalige zonne-energie op het areaal van Rijkswaterstaat (bermen van snelwegen, geluidsschermen, vaarwegen). Voorbeelden van kleinschalige maatregelen zijn zonnepanelen op daken, lokale energiecoöperaties of projecten waarbij lokale opwekking wordt afgestemd op lokaal gebruik. Daarbij speelt niet slechts de gedachte dat een bijdrage wordt geleverd aan de energietransitie, maar spelen ook idealen als zeggenschap over de eigen leefomgeving en onafhankelijkheid van grote energiebedrijven.

Verschillende grootschalige oplossingen hebben een verschillende ruimtelijke impact. Zonnevelden zijn sterk in opkomst, mede omdat deze in sommige gevallen een meervoudig landgebruik toestaan. Bij veehouderij bijvoorbeeld kunnen de schapen en koeien gewoon tussen de zonnepanelen door lopen. Bovendien zijn deze betrekkelijk makkelijk in het landschap in te passen. Wind op land daarentegen is vanwege risicozonering minder geschikt voor meervoudig gebruik, zeker waar het gaat om bebouwing en in sommige gevallen ook om dijken, terwijl dit bij landbouw weer minder aan de orde is. Wind op land heeft daarnaast een grote visuele impact, omdat de turbines tot wel 200 meter hoog kunnen zijn. Zo is de Tweede Maasvlakte binnenkort eigenaar van een wereldprimeur: de grootste windturbine ter wereld, die tot $10 \mathrm{MW}$ kan opwekken. Hiermee worden ten minste 8000 huishoudens per jaar van elektriciteit voorzien. De tiphoogte van deze turbine is 250 meter. Hoewel een zonneveld in dat opzicht een minder groot bereik heeft, is de energiewinst van wind op land vele malen groter. Een gemiddelde turbine met een opwek van $3 \mathrm{MW}$ per jaar staat ongeveer gelijk aan 10 hectare zonneveld qua energieopbrengst. Een zonneveld heeft derhalve een veel groter landgebruik. ${ }^{15}$

Wind op zee kan een zeer grote rol gaan spelen in de verduurzaming van de Nederlandse elektriciteitsopwekking. Een aandeel van $70 \mathrm{GW}$ wind op zee is technisch mogelijk. Natuurlijk moeten de besluitvormingsprocedures daartoe ook andere belangen, zoals natuur en biodiversiteit en scheepvaart, meewegen, maar een substantiële verhoging van het aandeel wind op zee houdt auto- matisch ook in dat het hoogspanningsnet afdoende uitgebreid moet worden. Dit kan near shore worden gerealiseerd, waarbij het ruimtebestek op zee plaatsvindt, maar vanwege financiële afwegingen kan dit ook aan land worden gerealiseerd, waarbij het ruimtelijk beslag in of nabij de duinen plaatsvindt.

Dit betreft de grootschalige oplossingen. Andere oplossingen, zoals zonnepanelen op daken, gecombineerd met (buurt)batterijen en onderlinge uitwisseling van elektriciteit, hebben een veel minder groot ruimtelijk beslag omdat hier gebruik kan worden gemaakt van meervoudig landgebruik: de gebouwde omgeving bestaat al en zonnepanelen kunnen daarop gerealiseerd worden. TNO voorspelt voor de gebouwde omgeving dat deze op den duur energie producerend kan worden; dit door middel van energiebesparing en energie-efficiëntie, kleinschalige elektriciteitsopwekking en slimme toepassingen door middel van opslag, het leveren van flexibiliteit en het slim gebruik van laadpalen van elektrische auto's. Een energie producerende gebouwde omgeving betekent een substantieel lagere vraag naar grootschalige elektriciteitsopwekking, onder andere door windmolenparken op land en zee.

De keuze voor grootschalige oplossingen is met name ingegeven door de energieopbrengst, daar deze het snelst bijdragen aan het verhogen van het aandeel hernieuwbare energie en het verlagen van $\mathrm{CO}_{2}$-uitstoot. Echter, door enkel voor deze grootschalige oplossingen te kiezen, wordt het potentieel van de opschaling van deze kleine oplossingen ontkend. Elektriciteitsproductie-installaties realiseren die later niet nodig blijken te zijn, betekent dat zeer laaghangend fruit niet benut wordt. Tegelijkertijd moeten we ons ook niet blindstaren op het potentieel in de gebouwde omgeving, aangezien ook dit een behoorlijk financieel kostenplaatje met zich mee zal brengen.

Een tweede 'dilemma' betreft de vraag of de leefomgeving bij het maken van een keuze tussen mogelijke transitiepaden wel of niet leidend moet zijn. Zo kan worden aangesloten bij de bestaande structuur van de leefomgeving, cultuurhistorische waarden of landschappen, bijvoorbeeld door zonnepanelen zo veel mogelijk op daken te leggen, windturbines vooral op zee te plaatsen en bepaalde gebieden te vrijwaren van windturbines. Daartegenover staat de mogelijkheid om nieuwe landschappen te ontwikkelen, bijvoorbeeld door wind- en zonneenergie vooral geconcentreerd te plaatsen in 'nationale energielandschappen'. Het is een feit dat de energietransitie landschappen zal veranderen. Er zal dus ook moeten worden gediscussieerd over welke landschappen onveranderd moeten blijven en waar nieuwe landschappen kunnen worden gerealiseerd. 


\section{Twee transitiepaden: van fossiel naar wind, van gas naar duurzame warmtebron}

Hierboven kwam kort ter sprake dat met name het belang van $\mathrm{CO}_{2}$-emissiereductie, maar zeker ook de besluitvorming omtrent aardgaswinning in Groningen, leidt tot het streven van de overheid om de energievoorziening te verduurzamen. Anticiperend op technologische, economische en sociaal-maatschappelijke innovatie - en daaraan verbonden onzekerheden - is in de Energieagenda gekozen voor een aanpak die zich niet richt op specifieke energiebronnen en -dragers, maar op de vier maatschappelijke functionaliteiten van energie: kracht en licht (licht, elektrische apparaten), hoge temperatuurwarmte (bijvoorbeeld proceswarmte voor industrie), lage temperatuurwarmte (ruimteverwarming en warm tapwater) en transport en mobiliteit. Voor deze functionaliteiten is in de Energieagenda op hoofdlijnen een eigen transitiepad opgenomen. ${ }^{16}$ Binnen deze hoofdlijnen zullen veel keuzes moeten worden gemaakt. Zo is er in het regeerakkoord voor gekozen om voor 2030 alle kolencentrales te sluiten. Thans wordt in deze kolencentrales $4660 \mathrm{MW}$ opgewekt. Het verlies van dit opgestelde vermogen kan worden opgevangen met de productie van hernieuwbare elektriciteit, zoals zonneparken en windturbineparken. ${ }^{17}$ Een alternatieve oplossing voor het sluiten van de kolencentrales zou kunnen zijn dat in de drie 'jonge' kolencentrales de bijstook van biomassa substantieel verhoogd wordt en tegelijkertijd $\mathrm{CO}_{2}$-uitstoot wordt opgevangen en ondergronds opgeslagen (CCS). CCS staat als $\mathrm{CO}_{2}$-reductiemaatregel uitdrukkelijk genoemd in het regeerakkoord. Kortom, er zijn meerdere alternatieve duurzame oplossingsrichtingen denkbaar.

De warmtetransitie - het vervangen van aardgas door meer duurzame energiedragers voor de warmtevoorziening - is een verandering die nog verder reikt dan enkel het verduurzamen van de productie van elektriciteit. Voor de warmtevoorziening zijn er namelijk drie mogelijke energiedragers, die elk een ander systeem (infrastructuur, afleverinstallatie) vereisen. ${ }^{18}$ Kort gezegd zijn er drie energiedragers die aardgas kunnen vervangen: warm water uit collectieve warmtenetten, elektriciteit voor bijvoorbeeld warmtepompen en elektrisch koken, en duurzaam gas, zoals biogas, methaan of waterstof. Waar duurzame elektriciteit in principe via het bestaan-

16. Ministerie van Economische Zaken, Energieagenda, Den Haag: Ministerie van Economische Zaken 2016, p. 8.

17. De transitie is een systeemverandering, waarbij veranderingen van elementen van het systeem bepaalde ruimtelijke gevolgen kunnen hebben. Verschillende technieken om op een duurzame manier energie op te wekken kunnen worden gezien als knoppen op een mengpaneel, waaraan kan worden gedraaid met steeds een nieuwe configuratie als gevolg. De gewenste configuratie is onder meer afhankelijk van wensen en eisen ten aanzien van de fysieke leefomgeving. Zie ook Posad Spatial Strategies e.a. 2018, p. 15-16.

18. Posad Spatial Strategies e.a. 2018, p. 175 e.v. de net kan worden getransporteerd en geleverd, ${ }^{19}$ vereisen nieuwe systemen voor de warmtevoorziening soms aanpassingen 'achter de voordeur' in de vorm van extra isolatiemaatregelen, ${ }^{20}$ installatie van een warmtewisselaar ${ }^{21}$ of een elektrische kookplaat.

Bij het maken van keuzes ten aanzien van duurzaamheidsmaatregelen spelen verschillende partijen een rol: de centrale en decentrale overheden, marktpartijen, eindgebruikers en investeerders. Momenteel ligt de bal nog voor een groot deel bij de rijksoverheid, omdat zij nog verschillende keuzes kan maken ten aanzien van de energietransitie. Zij kan bijvoorbeeld in het licht van bindende doelen voor $\mathrm{CO}_{2}$-emissiereductie en het aandeel hernieuwbare energie verantwoordelijkheden verdelen, bevoegdheden ter uitvoering van die verantwoordelijkheden in het leven roepen en randvoorwaarden stellen aan de uitvoering daarvan. Zij kan ook een sterk regisserende rol op zich nemen, waarin zij deze doelen nader invult door keuzes te maken voor bronnen of technieken.

Met betrekking tot de twee transitiepaden zoals hierboven geschetst, vervult de overheid verschillende rollen. In de deeltransitie van fossiel naar windenergie heeft zij ervoor gekozen een sterke regierol op zich te nemen, door bron, techniek, omvang en locaties te kiezen. Vervolgens is deze regierol overgedragen an de provincie, die is uitgerust met doorzettingsmacht om de rijksdoelstellingen te halen (zie par. 4).

Met betrekking tot de warmtetransitie lijkt de rijksoverheid een ander pad te nemen. Enerzijds wordt de doelstelling bepaald - van gas af, uiterlijk in 2050 -, maar de nadere invulling van dat doel wordt overgelaten aan gemeenten. ${ }^{22}$ Desalniettemin bestaat ook bij collectieve, regionale warmtenetten de mogelijkheid dat het omgevingsrechtelijk instrumentarium wordt ingezet om grootschalige projecten te faciliteren (zie par. 5).

Hieronder beschrijven wij aan de hand van windenergie op land en de warmtetransitie hoe het omgevingsrechtelijk instrumentarium een rol kan spelen binnen de energietransitie. Daarna besteden wij aandacht aan de lessen die we hieruit kunnen leren ten aanzien van de rol van het omgevingsrecht in de energietransitie.

19. Dit betekent overigens niet dat er geen aanpassingen aan het elektriciteitsnet nodig zijn. De verwachte toename van elektriciteitsgebruik zal in gevallen leiden tot de noodzaak tot verzwaring van het elektriciteitsnet.

20. Lagetemperatuurvoorzieningen functioneren bijvoorbeeld alleen in goed geïsoleerde woningen en zijn dus niet voor elk woningtype geschikt. Zo moeten vooroorlogse woningen over het algemeen ingrijpende renovatie ondergaan om deze voor lagetemperatuurverwarming geschikt te maken.

21. Een warmtewisselaar is een apparaat dat warmte uit bijvoorbeeld een warmtenet overbrengt op de warmtevoorziening van een gebouw.

22. Ministerie van Economische Zaken 2016, p. 66, brief Wiebes. 


\section{Transitiepad 1: van fossiel naar windenergie}

Aangezien een substantieel deel van de $\mathrm{CO}_{2}$-uitstoot wordt veroorzaakt door de opwekking van energie met kolen, olie en gas, zullen deze energiebronnen onder meer door schonere bronnen moeten worden vervangen. Eén van deze duurzame bronnen waarop wordt ingezet, is wind. Nederland heeft een groot potentieel voor het opwekken van elektriciteit uit wind. Hoewel er in vergelijking met andere landen als Duitsland substantieel minder beschikbare ruimte is vanwege de bevolkingsdichtheid en infrastructuur, zijn er voldoende kansrijke gebieden beschikbaar waar grootschalig elektriciteit uit wind kan worden opgewekt, met name op zee. ${ }^{23}$ De keuze om windenergie een rol te laten spelen in de toekomstige energiemix is een rationele keuze.

\subsection{De opgave}

In het Energieakkoord zijn doelstellingen ten aanzien van windenergie vastgesteld. Voor wind op land is het streven om een opgesteld vermogen windenergie van $6000 \mathrm{MW}$ te hebben gerealiseerd. Naar aanleiding van deze rijksdoelstelling zijn er tussen het Rijk en de provincies afspraken gemaakt die zijn neergelegd in de Structuurvisie Windenergie op Land (SV WoL), die in maart 2014 door het kabinet is vastgesteld. ${ }^{24}$ Daar de doelstelling vrij omvangrijk is, is besloten deze te realiseren door middel van grootschalige windturbineparken, elk van $350 \mathrm{MW}$ of meer, zowel voor wind op land als voor wind op zee. ${ }^{25}$ Voor het realiseren van deze doelstelling is een nauwkeurig overheidsbesluitvormingsproces met vele omgevingsrechtelijke instrumenten ontwikkeld.

\subsection{Ruimtelijk beleid voor windenergie: realiseren van rijksdoelstellingen en voorkomen 'verrommeling'}

Het ruimtelijk kader ten aanzien van windenergie is al ver ontwikkeld en kan worden onderverdeeld in beleid en regelgeving ten aanzien van windenergie op zee, waarbij het Rijk een coördinerende taak heeft, en wind op land, waarbij provincies de regierol hebben. Deze regierol komt tot uitdrukking in ruimtelijke bevoegdheden ter vergroting van provinciale doorzettingsmacht bij windturbineprojecten.

Doordat provincies hun ruimtelijk beleid ten aanzien van windturbines hebben opgesteld in het kader van de doelstellingen uit het Energieakkoord, ligt de nadruk van dit beleid op het anwijzen van locaties waar grootschalige windturbineparken kunnen worden gerealiseerd en regels ter voorkoming van 'verrommeling' van het

23. Sijmons e.a. 2017, p. 102-103

24. Ministerie van Infrastructuur en Milieu \& Ministerie van Economische Zaken, Structuurvisie Windenergie op Land, Den Haag: Ministerie van Infrastructuur en Milieu en Ministerie van Economische Zaken 2014, p. 33-34.

25. SER 2013, p. 68-73 landschap. Dit beleid heeft geleid tot beperkingen van de mogelijkheden voor gemeenten om eigen ruimtelijk beleid ten anzien van windenergie te maken. Gemeenten dienen zich namelijk bij het ontwikkelen van windenergieprojecten te houden an provinciale regels. In deze paragraaf staan het ruimtelijk beleid en regelgeving ten aanzien van wind op land centraal.

De hoofdlijnen van ruimtelijk beleid ten aanzien van de energievoorziening zijn neergelegd in de Structuurvisie Infrastructuur en Ruimte (SVIR). In deze structuurvisie is het rijksbeleid voor de ruimtelijke inrichting en de infrastructuur van Nederland tot 2040 opgenomen. De SVIR vormt als het ware een 'kapstok' voor uitwerkingen van beleid met ruimtelijke consequenties. Deze uitwerking van de hoofdlijnen vindt plaats door middel van aspectstructuurvisies.

Een van de nationale belangen die in de SVIR worden herleid uit de doelstellingen van ruimtelijk beleid is het creëren van voldoende ruimte voor het hoofdnetwerk voor (duurzame) energievoorziening en energietransitie. ${ }^{26}$ Dit is primair de taak van provincies en gemeenten, terwijl het Rijk zich, gelet op de grote invloed op de omgeving en de omvang van deze opgave, beperkt tot grootschalige windenergie op land en op zee. ${ }^{27}$ Dit is nader uitgewerkt in de SV WoL en de Structuurvisie Windenergie op Zee (SV WoZ).

In de SV WoL is beleid geformuleerd om windturbines in daarvoor geschikte gebieden te concentreren om versnippering en verstoring van het landschap zo veel mogelijk te beperken. Daarnaast zijn hierin ook de afspraken tussen het kabinet en de provincies opgenomen met betrekking tot de doelstelling om in 20206000 MW windvermogen te hebben gerealiseerd.

\subsubsection{Grootschalige mindturbineparken}

Ten aanzien van windenergie op land wordt in de Chw een onderscheid gemaakt tussen drie categorieën windturbineparken, die worden onderscheiden naar vermogen. De eerste categorie windturbineparken telt een vermogen van $100 \mathrm{MW}$ of meer en wordt angeduid als project van nationaal belang, waardoor deze onder de rijkscoördinatieregeling valt. Dit houdt in dat het Rijk zelf het ruimtelijk besluit neemt en nadere besluitvorming, zoals het verlenen van een omgevingsvergunning, coördineert.

\subsubsection{Middelgrote en kleine mindturbineparken}

Ten aanzien van de tweede categorie windturbineparken - met een vermogen van ten minste 5 tot $100 \mathrm{MW}$ - zijn bij inwerkingtreding van de Chw enkele provinciale taken ten aanzien van windturbineparken opgenomen in de Elektriciteitswet om de doorzettingsmacht van provincies te versterken. Het belang van het behalen van rijksdoelstellingen voor duurzame energie is hiervoor de

Ministerie van Infrastructuur en Ruimte, Structuurvisie Infrastructuur en Ruimte. Nederland concurrerend, bereikbaar, leefbaar en veilig, Den Haag: Ministerie van Infrastructuur en Ruimte 2012, p. 35.

27. Ministerie van Infrastructuur en Ruimte 2012, p. 35. 
reden geweest. $^{28}$ Op grond van deze bevoegdheid mogen provinciale staten een inpassingsplan vaststellen voor productie-installaties van windenergie, met inbegrip van de aansluiting van die installatie op een net. ${ }^{29}$ Provinciale staten geven in ieder geval toepassing aan deze bevoegdheid indien een producent het voornemen tot aanleg of uitbreiding van een windturbinepark schriftelijk meldt, of indien de betrokken gemeente een aanvraag van die producent tot vaststelling of wijziging van een bestemmingsplan ten behoeve van de realisatie van dat voornemen heeft afgewezen. ${ }^{30}$ De in de wet opgenomen verplichting tot vaststelling van een inpassingsplan voor een windturbinepark heeft uitsluitend betrekking op de toepassing van de bevoegdheid en niet op de inhoud daarvan. Mochten provinciale staten tot de conclusie komen dat de gronden waarvoor de gemeenteraad een verzoek tot vaststelling heeft afgewezen, niet geschikt zijn voor de toepassing van windenergie, dan impliceert art. 9e lid 2 Elektriciteitswet dat provinciale staten verplicht zijn een alternatieve locatie te zoeken voor de toepassing van windenergie en daarvoor een inpassingsplan vast te stellen. ${ }^{31}$

Voor besluitvorming ten aanzien van windturbineparken tot $5 \mathrm{MW}$ ten slotte is de gemeente het bevoegde bestuursniveau. De vrijheid van de gemeente om eigen beleid te voeren ten aanzien van windenergie wordt echter begrensd door het provinciaal ruimtelijk beleid en regels ten aanzien van windturbineparken en losse windturbines. Dit leidt in sommige gevallen tot conflicten, waarbij lokale windprojecten door de provincie worden doorgestreept of de provincie juist haar doorzettingsmacht gebruikt om de lokale ruimtelijke belangenafweging met het oog op de te realiseren provinciale doelstellingen voor windenergie te overrulen en een windturbinepark te realiseren.

\subsection{Het provinciaal ruimtelijk kader voor windenergie}

Ten behoeve van de doorwerking van provinciaal beleid beschikken provincies over verschillende instrumenten. In de eerste plaats kan een provincie haar beleid uiteenzetten in één of meer structuurvisies. Naar aanleiding van het ruimtelijk beleid dat in de structuurvisies op hoofdlijnen wordt uiteengezet, kunnen bij provinciale verordening regels worden gesteld. Daarnaast kunnen provincies door middel van inpassingsplannen rijks- en provinciaal beleid laten doorwerken in gemeentelijke bestemmingsplannen.

\subsubsection{Provinciale structuurvisies}

De Wet ruimtelijke ordening (Wro) schrijft voor dat provinciale staten voor het hele grondgebied van de provincie een structuurvisie opstellen, waarin ten behoeve van de goede ruimtelijke ordening de hoofdzaken van het door de provincie te voeren ruimtelijk beleid zijn

28. Kamerstukken II 2009/10, 32 127, nr. 3, p. 22.

29. Art. 9e lid 1 Elektriciteitswet.

30. Art. 9e lid 2 Elektriciteitswet.

31. A.Ch. Fortgens, Ruimte voor energie, BR 2015/19, p. 10. vastgelegd..$^{32}$ Voor zover een structuurvisie ontwikkelingen omvat, gaat deze in op de wijze waarop provinciale staten zich voorstellen die ontwikkelingen te verwezenlijken. ${ }^{33}$ Hierin kan ook het beleid ten aanzien van windenergie worden opgenomen. Daarnaast is het mogelijk om een zogenoemde aspectstructuurvisie vast te stellen voor het ruimtelijk beleid ten aanzien van windenergie. $^{34}$

De structuurvisie heeft een indicatief karakter. Het doel is om een beeld te schetsen van voorgenomen beleid. Om dit beleid een meer normatieve betekenis toe te kennen kan dat worden vervat in de regels van de provinciale ruimtelijke verordening.

\subsubsection{Provinciale ruimtelijke verordening}

De ruimtelijke verordening is een belangrijk sturingsinstrument voor de provincie. De algemene regels die bij verordening kunnen worden gesteld, kunnen worden onderverdeeld in enerzijds instructie- of interbestuurlijke regels die zijn gericht tot bestuursorganen van lagere overheden $^{35}$ en anderzijds extern werkende regels die zich ook kunnen richten tot burgers en bedrijven. ${ }^{36} \mathrm{De}$ verordening is bedoeld als een proactief sturingsinstrument. ${ }^{37}$ Gemeenten dienen er, met andere woorden, voor te zorgen dat bestaande bestemmingsplannen en beheersverordeningen in principe binnen een jaar aan deze regels worden aangepast. ${ }^{38}$ Strijd met de provinciale verordening kan leiden tot vernietiging door de bestuursrechter of een reactieve aanwijzing, die als gevolg heeft dat (een onderdeel van) het bestemmingsplan of een andere planologische maatregel waarop de reactieve aanwijzing betrekking heeft, niet in werking treedt. ${ }^{39}$ In provinciale ruimtelijke verordeningen worden doorgaans instructieregels gegeven over de wijze waarop in bestemmingsplannen in de mogelijkheid kan worden voorzien om windturbines op te richten. Deze zijn er in het algemeen op gericht om verrommeling van het landschap te voorkomen door de ontwikkeling van nieuwe windturbines te beperken en door beperkende regels ten aanzien van het vervangen van bestaande turbines.

\subsection{Doorzettingsmacht van Rijk en provincie en gevolgen voor de lokale ruimtelijke besluitvorming}

Vanwege het belang voor het behalen van rijksdoelstellingen voor duurzame energie is de doorzettingsmacht

\footnotetext{
32. Art. 2.2 lid 1 Wro.

33. Art. 2.2 lid 3 Wro.

34. Art. 2.2 lid 2 Wro

35. Meer specifiek zijn instructieregels algemene regels die uitsluitend gericht zijn tot het bestuursorgaan dat het bestemmingsplan, de beheersverordening of de omgevingsvergunning voor het afwijken van het bestemmingsplan vaststelt (art. 4.1 lid 1 Wro).

36. Art. 4.1 lid 3 Wro.

37. Onder het oude systeem van de WRO gold de provinciale goedkeuring gemeentelijke bestemmingsplannen als het voornaamste instrument voor de effectuering van het provinciaal ruimtelijk beleid.

38. Art. 4.1 lid 2 Wro. In de verordening kan ook een andere termijn worden gesteld.

39. Art. 3.8 lid 6 Wro.
} 
van het Rijk, maar met name van de provincies ten aanzien van windenergie met de Chw aanzienlijk versterkt. De regierol die de wetgever de provincie hiermee heeft toebedeeld, is in het licht van de doelstelling voor wind op land in het Energieakkoord nader uitgewerkt. Zo hebben de provincies afspraken met het Rijk gemaakt over een verdeling van het $6000 \mathrm{MW}$ opgesteld vermogen wind op land dat voor 2020 moet worden gerealiseerd. Naar aanleiding van deze doelstellingen zijn in provinciale ruimtelijke verordeningen instructieregels opgenomen ten aanzien van windenergie, die enerzijds moeten zorgen dat de doelstellingen worden gehaald, maar anderzijds vaak ook moeten voorkomen dat het landschap 'verrommelt'. ${ }^{40}$ De keuze voor 'centrale' doorzettingsmacht heeft de vrijheid van gemeenten om zelf ruimtelijk beleid ten aanzien van windenergie op te stellen sterk ingeperkt, wat nogal eens tot conflicten leidt, zoals recent in Amsterdam, waar de provincie Noord-Holland weigerde om vergunningen af te geven voor 23 windturbines in het havengebied van Amsterdam, omdat deze niet voldeden aan de strenge eisen van de provinciale verordening. ${ }^{41}$ Een ander voorbeeld is de meer dan twintig jaar oude dorpsmolen van het Friese Reduzum, waarvan de plannen om deze te vervangen door een hoger, meer renderend exemplaar ondanks groot maatschappelijk draagvlak en goedkeuring van de gemeente Leeuwarden spaak lopen op beperkende provinciale regels voor nieuwe solitaire windturbines. Ook de doorzettingsmacht van het Rijk ten aanzien van grootschalige windturbineparken leidt tot conflicten, zoals bij het windturbinepark Drentse Monden en Oostermoer. $^{42}$

\section{Transitiepad 2: van aardgas naar duurzame warmte}

Waar het juridisch kader ten aanzien van windenergie zich al in een vergevorderd stadium bevindt, moet het juridisch kader ten aanzien van de warmtetransitie nog grotendeels vorm krijgen. De warmtevraag kan in het licht van de eerdergenoemde energiefunctionaliteiten worden opgesplitst in een hogetemperatuurwarmtevraag (industriële proceswarmte) en een lagetemperatuurwarmtevraag (ruimteverwarming gebouwen en warm tapwater). In deze bijdrage gaan we in op de verduurzaming van de verwarming van de gebouwde omgeving een opgave die sterk in de belangstelling is komen te staan sinds de aardbeving in Zeerijp in januari 2018 en het besluit van de minister van Economische Zaken en

40. Onder meer ten gevolge van de keuze voor steeds grotere windturbines (as- en tiphoogte van meer dan 100 tot 200 meter) zijn provincies beleidsmatig steeds indringender gaan nadenken over de plaatsing daarvan.

41. Het ging onder meer om de eis dat voor elke nieuwe windturbine twee oude moeten worden verwijderd. Zie ABRvS 30 augustus 2017, ECLI:NL:RVS:2017:2331.

42. ABRvS 21 februari 2018, ECLI:NL:RVS:2018:616.
Klimaat (EZK) om de gaswinning uiterlijk in 2030 te stoppen. $^{43}$

\subsection{De opgave}

Hoewel het besluit om de gaswinning op termijn te stoppen heeft geleid tot opleving van de discussie over het terugdringen van het aardgasgebruik, zijn er ten aanzien van het gebruik nog geen concrete besluiten genomen. Momenteel is het streven om in 2050 weinig tot geen broeikasgassen meer uit te stoten. Dat betekent voor de gebouwde omgeving dat er in ieder geval voor die tijd andere, meer duurzame methoden moeten worden gezocht om deze te verwarmen. Een substantieel deel van de reductiedoelstelling voor 2030 uit het regeerakkoord (49\%) zal via verduurzaming van de gebouwde omgeving moeten worden behaald. ${ }^{44}$ Deze opgave is niet gering: de gebouwde omgeving is nu namelijk voor ruimteverwarming en verwarming van tapwater voor zo'n 90\% afhankelijk van aardgas.

\subsection{Gasaansluitplicht}

Een belangrijke belemmering voor het verduurzamen van de warmtevoorziening van de gebouwde omgeving is de plicht voor de netbeheerder om bij eenieder die daarom verzoekt een gasaansluiting te realiseren. ${ }^{45} \mathrm{De}$ eerste stappen richting een oplossing voor dit probleem zijn reeds gezet. Onlangs is de Wet Voortgang Energietransitie (Wet VET) door beide Kamers van het parlement aangenomen. Deze wet wijzigt onder meer de Gaswet, waardoor het uitgangspunt wordt dat nieuwbouw niet op het gasnet wordt aangesloten en dus beschikt over een alternatieve warmtevoorziening. ${ }^{46}$ Hiermee is ten aanzien van nieuwbouw de eerste horde voor verduurzaming van de warmtevraag genomen. ${ }^{47}$

\subsection{Bestaande gebouwde omgeving grootste opgave}

De grootste opgave in de warmtetransitie vormt het verduurzamen van de warmtevoorziening van bestaande gebouwen. Het kabinet heeft zich tot doel gesteld om deze kabinetsperiode 30.000-50.000 woningen aardgasvrij of aardgasvrij-ready te maken. ${ }^{48}$

Ten aanzien van bestaande gasaansluitingen bestaat het voornemen om de gasaansluitplicht en het daaruit herleide 'recht op een gasaansluiting' te vervangen door een 'techniekneutraal warmterecht', wat neerkomt op een recht op een aansluiting op de lokaal beschikbare warmtevoorziening. ${ }^{49}$ Voor de invulling van dat warmterecht bestaan meerdere mogelijkheden: in de eerste plaats kunnen warmte en warm tapwater worden aangeleverd via collectieve warmtenetten die worden ingevoed met

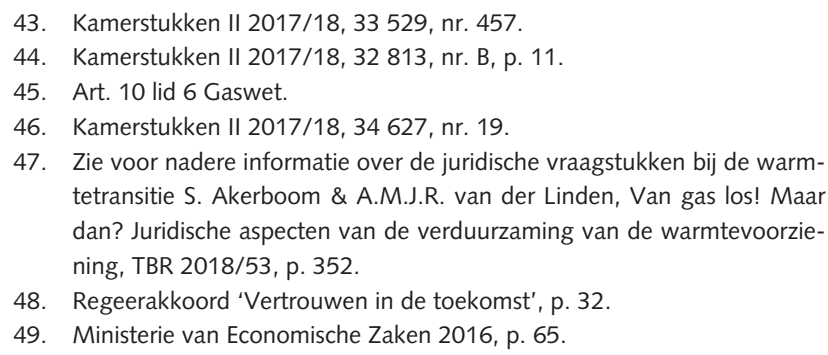


restwarmte en warmte uit geothermie. Dit zijn doorgaans grootschalige oplossingen die onder andere veel voorinvesteringen vereisen, zoals het aanleggen van infrastructuur, het isoleren van gebouwen en het aanboren van aardwarmte. ${ }^{50}$ Voor dergelijke projecten is het belangrijk om ook een langetermijnplan te hebben voor de leveringszekerheid - bijvoorbeeld door warmtenetten open te stellen voor toekomstige restwarmteleveranciers - en het verduurzamen van warmtebronnen. ${ }^{51}$ In de tweede plaats kunnen op kleinere schaal individuele of blokgewijze voorzieningen met warmte-koudeopslag (wko), hybride warmtepompen of elektrische warmtepompen een uitkomst bieden. Deze warmtevoorzieningen vergen echter vergaande isolatiemaatregelen en verhogen de elektriciteitsvraag. Ten slotte zal in sommige gebieden (met name agrarische gebieden) groen gas een optie kunnen zijn, waarvoor het bestaande gasnet kan worden gebruikt. Op de langere termijn zou het bestaande aardgasnet ook kunnen worden gebruikt voor het transport van waterstof. Hoe deze techniek zich gaat ontwikkelen en welke rol deze eventueel in de warmtevoorziening kan spelen, is echter nog niet bekend.

De keuze voor een van bovenstaande oplossingen is afhankelijk van lokale wensen en omstandigheden: Wanneer moet een aardgasnet worden vervangen (en moet er dus worden gedacht aan een alternatieve warmtevoorziening)? Welke techniek past bij de warmtevraag van gebouwen? ${ }^{52}$ Zijn er lokaal of regionaal (duurzame) warmtebronnen aanwezig? Moeten er gebouwgebonden maatregelen worden getroffen, zoals het aanbrengen van (extra) isolatie en het installeren van vloerverwarmingen of convectoren? Dit vergt een gebiedsgebonden aanpak. Naast technische keuzes spelen uiteraard ook kwesties ten aanzien van de kosten.

Vanwege deze contextafhankelijkheid en aanpak op wijk- en gebiedsniveau is de rijksoverheid voornemens om de regierol in de eerste plaats bij de gemeente (in samenwerking met de netbeheerder) te leggen. ${ }^{53}$ Afhankelijk van het schaalniveau van gekozen maatregelen om de warmtevraag te verduurzamen (bijvoorbeeld een regionaal of lokaal warmtenet met een collectieve warmtebron of individuele warmtepompen), kunnen plannen regionaal worden afgestemd en afspraken worden gemaakt via het Interbestuurlijk Programma (IBP). ${ }^{54}$

50. Posad Spatial Strategies e.a. 2018, p. 202-203

51. Zo zijn restwarmtebronnen vaak gebonden aan energie-efficiëntie-eisen uit het Activiteitenbesluit en zullen dus op termijn minder restwarmte produceren. Daarnaast wordt door rijksbeleid ten aanzien van een circulaire economie gestreefd naar de reductie van afvalverbranding. Ten slotte zijn geothermiebronnen niet onbeperkt bruikbaar.

52. De warmtevraag van de gebouwde omgeving is onder meer afhankelijk van gebouwtype, bouwjaar en bebouwingsdichtheid

53. Nadere invulling van de regierol van de gemeente bij de warmtetransitie is onderwerp bij de onderhandelingen van het Klimaatakkoord (Kamerstukken II 2017/18, 32 813, nr. B, p. 10).

54. Ministerie van Economische Zaken 2016, p. 66; Kamerstukken II 2017/18, 32 813, nr. B, p. 10. Het IBP is de basis voor samenwerking tussen verschillende overheden om vraagstukken aan te pakken die de grenzen van gemeente, regio of bepaalde beleidsterreinen overschrijden, waaronder de energietransitie. Zie Kamerstukken II 2017/18, 29362 , nr. 266.
Hoewel in de Energieagenda werd gezinspeeld op het vaststellen van lokale en regionale energieplannen, ${ }^{55}$ is nog niet duidelijk met welke instrumenten de gemeente de lokale warmtetransitie zou moeten vormgeven.

\subsection{Bestaande instrumenten}

Traditioneel valt de keuze tussen een gas- en warmtenet onder de bevoegdheden van de gemeente. Zo kan de gemeenteraad inzake de aanleg van een warmtenet voor bepaalde gebieden een warmteplan opstellen. Dit is een besluit dat voor een periode van tien jaar wordt genomen en waarin het voor die periode geplande aantal aansluitingen is opgenomen. Ook wordt in het warmteplan de mate van energiezuinigheid en bescherming van het milieu bij aansluiting opgenomen. Dit wordt gebaseerd op de energiezuinigheid van het distributienet en het opwekkingsrendement van de over het net getransporteerde warmte. ${ }^{56}$

Wanneer er voor een bepaald gebied een warmteplan is vastgesteld, heeft dit twee rechtsgevolgen. In de eerste plaats is er in het betreffende gebied sprake van een aansluitplicht voor nieuwbouw op het warmtenet indien het in het warmteplan geplande aantal aansluitingen op dat distributienet op het moment van indienen van de aanvraag om een vergunning voor het bouwen nog niet is bereikt ${ }^{57}$ en de afsluitafstand niet groter is dan 40 meter, of groter is dan 40 meter en de aansluitkosten niet hoger zijn dan bij een aansluitafstand van 40 meter. ${ }^{58}$ Op deze plicht kan een uitzondering worden gemaakt op basis van het gelijkwaardigheidsbeginsel uit het Bouwbesluit. Een alternatieve warmtevoorziening moet dan ten minste dezelfde mate van energiezuinigheid en bescherming van het milieu hebben als wordt bereikt met de in het warmteplan voor die aansluiting opgenomen mate van energiezuinigheid en bescherming van het milieu. ${ }^{59}$

Naast het in het leven roepen van een aansluitplicht op het warmtenet heeft het vaststellen van een warmteplan als gevolg dat kleinverbruikers in het gebied van het warmtenet krachtens de Gebiedsindeling Gas Regionale Netbeheerders (Gas RNB) geen recht hebben op een aansluiting op het gasdistributienet. ${ }^{60}$

Omdat de optie van het warmteplan slechts betrekking heeft op gebieden waar een warmtenet ligt of komt te liggen, en is gericht op nieuwbouw, biedt dit instrument slechts beperkte mogelijkheden. Een warmteplan - en de mogelijkheid van uitzondering op de gasaansluitplicht - voor all electric-maatregelen bestaat niet.

\subsubsection{Een regionaal en/of gemeentelijk marmtetransitieplan?}

In het regeerakkoord is aangegeven dat met gemeenten, provincies, waterschappen en netbeheerders per regio

55. Ministerie van Economische Zaken 2016, p. 65.

56. Art. 1.1 lid 1 Bouwbesluit.

57. NB De aansluitplicht vervalt dus wanneer het in het warmteplan geplande aantal aansluitingen is bereikt.

58. Art. 6.10 lid 3 Bouwbesluit.

59. Art. 1.3 lid 3 Bouwbesluit.

60. Art. 4.2 onder a Code Gebiedsindeling Gas. 
een plan voor verduurzaming van de gebouwde omgeving wordt gemaakt. Deze samenwerking zal plaatsvinden op basis van de IBP-aanpak. ${ }^{61} \mathrm{Op}$ het gebied van aardgasvrije buurten en wijken ligt de regierol bij de gemeente. Het is echter nog de vraag welke instrumenten de gemeente kan aanwenden om deze rol te vervullen. Het ligt voor de hand dat de warmtetransitie ook een rol gaat spelen in het ruimtelijk beleid van gemeenten en dat het ruimtelijk instrumentarium daarvoor zal worden ingezet. Wellicht kan daarbij in de toekomst gebruik worden gemaakt van de systematiek van de Omgevingswet. Daarbij kan bijvoorbeeld worden gedacht aan een programma voor verduurzaming van de energievoorziening in een bepaald gebied. ${ }^{62}$

\subsection{Provinciaal beleid ten behoeve van een regionale warmtevoorziening}

De mogelijkheid om warmte met een laag temperatuurverlies over grote afstanden te transporteren maakt regionale warmtenetten mogelijk. Zo is het programmabureau Warmte-Koude Zuid-Holland momenteel bezig met het realiseren van een 'warmterotonde', waarbij restwarmte uit de Rotterdamse haven via een 'backbone' naar Dordrecht, het Westland, Delft, Den Haag en Leiden wordt getransporteerd. ${ }^{63}$ Daarbij treedt over meer dan 40 kilometer slechts één graad temperatuurverlies op. De infrastructuur en het geschikt maken van productieprocessen voor uitkoppeling van warmte ${ }^{64}$ vereisen echter hoge investeringen, terwijl er geen toekomstige afnamegarantie is. De huidige koppeling van de warmte- en gasprijs maakt daarnaast de inkoopprijs voor restwarmte laag, wat warmtelevering niet altijd interessant maakt voor bedrijven die warmteleverancier kunnen worden. Bovendien bestaan over de aansluiting van meer duurzame bronnen nog veel onduidelijkheden. Dit neemt natuurlijk niet weg dat restwarmte en regionale netten als maatregel voor verduurzaming moeten worden overwogen, maar het is belangrijk om te beseffen dat de businesscase van regionale warmtenetten een sterke prikkel kan zijn om in de toekomst provinciale regels te stellen, zoals instructieregels die voorschrijven dat gemeenten in hun omgevingsplan regels moeten opnemen met betrekking tot de aansluiting op een regionaal warmtenet. Met het in werking treden van de Omgevingswet worden regels met betrekking tot de aan-

61. IBP programmastart (Overhedenoverleg 14 februari 2018), p. 11 e.v. Zie ook noot 56.

62. Zie voor een beschouwing van juridische problematiek en oplossingsrichtingen naar aanleiding van de warmtetransitie Akerboom \& Van der Linden 2018.

63. Zie https://warmopweg.nl/warmterotonde.

64. Het overdragen van restwarmte uit industriële processen naar een warmtenet. sluiting op distributienetten voor energie opgenomen in het Omgevingsplan. ${ }^{65}$

\section{Analyse}

De energietransitie is in grote mate ook een ruimtelijke transitie. Terwijl fossiele opwekkingsinstallaties een grootschalig, centraal karakter hebben, zijn hernieuwbare opwekkingsinstallaties afhankelijk van natuurlijke omstandigheden, zoals bijvoorbeeld de windsnelheid of de aanwezigheid van een Natura 2000-gebied. Vanwege dergelijke belangen hebben hernieuwbare opwekkingsinstallaties nog niet dezelfde productiecapaciteit als fossiele centrales, zoals kolencentrales. Het ruimtelijk beslag van deze energie-infrastructuur is dan ook groter dan voorheen. De energietransitie, waarbij verschillende doelen voor 2030 zijn geformuleerd, zoals het aandeel van $27 \%$ hernieuwbare energie en $49 \% \mathrm{CO}_{2}$-reductie, heeft dan ook in toenemende mate een ruimtelijke impact.

Vooralsnog ziet het overheidsbeleid op de inpassing van grootschalige energie-infrastructuur, zoals wind op land en zee, maar ook op collectieve warmtenetten. De andere kant van de medaille van de energietransitie is dat energieconsumenten steeds vaker in staat zijn hun eigen energie op te wekken, bijvoorbeeld door middel van zonnepanelen, of in hun warmtebehoefte te voorzien door middel van warmtepompen. Inmiddels is een coöperatieve trend ontstaan waarin mensen zich met een buurt of straat verenigen om kleinschalige oplossingen te bedenken om energieonafhankelijk te worden.

Er zijn enkele gevallen bekend waarbij tussen deze groot- en kleinschalige hernieuwbare-energieoplossingen conflicten zijn ontstaan. Dit is bijvoorbeeld het geval tussen de provincie Noord-Holland en bewoners van Amsterdam, maar ook in Drenthe. Het is een redelijke verwachting dat deze conflicten zullen toenemen. Dit wordt deels veroorzaakt door de coördinerende rol die de rijksoverheid en provincies op zich hebben genomen, waardoor doelen op nationaal niveau worden benaderd en niet op lokaal niveau worden afgewogen. Dit terwijl een regionale aanpak, gebaseerd op de aanwezige bronnen en behoeften, een groot potentieel met zich mee kan brengen. Hieronder gaan wij nader in op drie punten.

\subsection{Ruimtelijk beleid voor de energietransitie} Voor de energietransitie geldt dat de keuze voor een bepaalde verduurzamingsmaatregel in nauwe samen-

65. Verplichtingen om aan te sluiten op een distributienet voor elektriciteit, gas of warmte uit het Bouwbesluit vervallen met inwerkingtreding van de Omgevingswet. In het Besluit bouwwerken leefomgeving (Bbl), een van de vier uitvoerings-AMvB's van de Omgevingswet waarin regels met betrekking tot bouwwerken zullen worden neergelegd, wordt hieromtrent niets meer geregeld. Gemeenten kunnen hiervoor lokale regels opstellen in het omgevingsplan. Zie par. 3.5.2 en 4.6.2 van de toelichting bij het $\mathrm{Bbl}$ 
hang moet worden bezien met de ruimtelijke aspecten daarvan. Via het ruimtelijk instrumentarium kunnen de gekozen duurzaamheidspaden worden vastgelegd en afgedwongen. Hiermee is een impliciete connectie ontstaan tussen het energiebeleid en het omgevingsrecht, waarbij het omgevingsrecht in zekere zin ten dienste kan komen te staan van de energietransitie. Hierboven hebben wij betoogd dat dit het geval is bij de ruimtelijke regelgeving voor windenergie (par. 3), en dat de mogelijkheid voor grootschalige oplossingen ter verduurzaming van de warmtevoorziening de mogelijkheid met zich meebrengt dat het omgevingsrecht wordt ingezet om de businesscase voor grootschalige warmtenetten sluitend te maken.

\subsection{Provinciale sturing en provinciaal belang} Vanwege het belang van het behalen van rijksdoelstellingen voor duurzame energie is de doorzettingsmacht van de provincies ten aanzien van windenergie met de Chw aanzienlijk versterkt. Gemaakte afspraken over windenergie tussen Rijk en provincies zijn vervolgens in provinciaal ruimtelijk beleid en regelgeving neergelegd, waarbij enerzijds het doel is om het afgesproken vermogen windenergie te realiseren, maar anderzijds ook om verrommeling van het landschap te voorkomen.

Het voorkomen van verrommeling van het landschap is een legitieme reden voor het stellen van provinciale regels ten aanzien van windturbines, maar heeft ook geleid tot de generieke afweging dat solitaire windturbines automatisch tot verrommeling leiden, terwijl er gebieden zijn waar in het landschap passende lokale windprojecten denkbaar zijn en waar ook draagvlak voor lokale windprojecten bestaat. In de praktijk heeft dit dikwijls tot conflicten geleid, waardoor de vraag rijst of dergelijke provinciale regels de lokale ruimtelijke afweging niet te veel beknotten.

Uiteraard worden energieplannen idealiter regionaal afgestemd, zodat maatregelen en oplossingen op zo veel mogelijk schaalniveaus kunnen worden gezocht en in verband kunnen worden gebracht met lokale en regionale ruimtelijke opgaven. Provincie en Rijk zouden in aanvulling daarop een coördinerende taak kunnen vervullen, zodat gemeenten kunnen profiteren van opgedane kennis en ervaring.

\subsection{De keuze voor grootschalige maatregelen en gevolgen voor lokale afweging}

Het streven om de lokale of regionale energievraag met maatregelen binnen hetzelfde gebied in te vullen - energieneutrale gebieden en regio's - kan ruimtelijke voordelen opleveren. Zo kan het lokaal of regionaal ruimtelijk afstemmen van energievraag en -aanbod bijvoorbeeld de noodzaak om extra transportleidingen te realiseren beperken. Het is echter nog maar de vraag of de som van lokale oplossingen voldoende zal zijn om gestelde klimaat- en energiedoelstellingen te halen. Zo zullen sommige regio's niet in hun eigen energievraag kunnen voorzien, terwijl andere regio's de potentie hebben om energieleverend te worden. ${ }^{66}$

Dat er na het halen van de doelstellingen voor 2020 nog meer grootschalige windturbineparken op land zullen worden gebouwd om de stijgende elektriciteitsvraag op duurzame wijze in te vullen, ligt voor de hand. ${ }^{67} \mathrm{De}$ afmeting van de benodigde windturbines en het aantal zullen afhangen van de behoefte, die ook weer mede afhankelijk is van keuzes in andere energiefunctionaliteiten (bijvoorbeeld een stijging van elektriciteitsvraag ten behoeve van ruimteverwarming).

De keuze voor schaalgrootte is als politieke keuze voorbehouden aan de overheid. Door voor grootschalige oplossingen te kiezen en het huidig omgevingsrechtelijk instrumentarium daarvoor toe te passen kunnen doelstellingen snel worden gerealiseerd. Zoals hierboven gezegd, kan dit gevolgen hebben voor de ruimte voor een lokale afweging.

\section{Conclusies}

De opgave om voor 2050 onze $\mathrm{CO}_{2}$-uitstoot drastisch te verlagen leidt onder meer tot de wens om de energievoorziening zo snel mogelijk te verduurzamen. Maatregelen waarmee grote slagen kunnen worden gemaakt, zijn een aantrekkelijke keuze. Hoewel de noodzaak voor verduurzaming groot is en de keuze voor grootschaligheid op zichzelf legitiem, blijft het nodig om te bezien welk effect dit streven heeft op de manier waarop ruimtelijk beleid wordt vormgegeven, en wat daarbij het uitgangspunt is. Zo heeft grootschaligheid er in het geval van windenergie toe geleid dat provinciale regelgeving de lokale ruimtelijke afweging kan beperken, wat niet altijd te rechtvaardigen is. Naar aanleiding van de huidige 'wildgroei' aan zonneparken wordt momenteel ook opgeroepen tot meer provinciale regie en de kans is dat er in de toekomst ook regels komen voor het aansluiten van restwarmteleveranciers en warmtegebruikers op regionale netten. Dergelijke regels zijn ongetwijfeld nuttig, maar het is van belang de vraag te stellen welke balans tussen energiebelangen en andere ruimtelijke belangen uiteindelijk leidt tot een goede ruimtelijke ordening. Met andere woorden: gaan we grootschalig 'inpassen' om meters te maken, iets waar Rijksadviseur voor de Fysieke Leefomgeving Berno Strootman onlangs voor waarschuwde, ${ }^{68}$ of gaan we creatief en slim ontwerpen, zodat energietransitie en ruimtelijke kwaliteit hand in hand gaan? Dat is een belangrijk onderdeel van de energietransitie, waarvan de aanpak ten slotte voor een belangrijk deel zal bepalen hoe het cultuurlandschap van de 21 ste eeuw eruit zal zien.

\footnotetext{
66. Posad Spatial Strategies e.a. 2018, p. 318.

67. Sijmons e.a. 2017, p. 129

68. A. van Dongen, Vrees voor landschap: straks helemaal 'gestoffeerd' met zonnepanelen, AD 26 april 2018.
} 
Het is van belang om in deze beginfase van de energietransitie te kijken wat de meerwaarde kan zijn van ruimtelijk beleid dat het mogelijk maakt om oplossingen op verschillende schaalniveaus te zoeken. Daarbij is het in ieder geval zaak om de ruimtelijke belangenafweging van de gemeente niet te beknotten met generieke provinciale of rijksregels, maar zo veel mogelijk ruimte te laten. Gemeenten zijn immers de overheid bij uitstek die een overzicht heeft van onderliggende belangen en conflicten die als uitgangspunt voor maatregelen kunnen dienen, en daartoe ook ruimtelijk beleid kan maken met oog voor omgevingskwaliteit. Daar waar regionale oplossingen mogelijk zijn, kan de provincie een betekenisvolle rol spelen als regisseur van gemeentelijke samenwerking en eventueel helpen met het delen van kennis, zodat gemeenten niet 'het wiel hoeven uit te vinden'. Een dergelijke aanpak past ook beter bij het uitgangspunt van het ruimtelijk recht 'decentraal wat kan, centraal wat moet' en in de toekomst het decentraliteitsbeginsel van de Omgevingswet.

In de nabije toekomst doen zich enkele kansrijke momenten voor om het zwaartepunt van de centrale en provinciale regierol opnieuw te beoordelen: in de eerste plaats de op te stellen regionale duurzaamheidsplannen in het kader van het Klimaat- en Energieakkoord, waarvoor in de zomer met de onderhandelingen is begonnen. Hierin worden lokale en regionale kansen en belemmeringen in kaart gebracht en uitgewerkt tot een strategie voor de verduurzaming van de energievoorziening.

In de tweede plaats, en wellicht nog belangrijker, zullen na 2023 - wanneer het doel van $6000 \mathrm{MW}$ op land gerealiseerd is - opnieuw keuzes moeten worden gemaakt ten behoeve van het duurzame energiebeleid. Daarbij kan opnieuw een afweging plaatsvinden welke maatregelen er moeten worden getroffen om verdere doelstellingen $(2030,2050)$ te realiseren en welk overheidsniveau hiervoor het meest geschikt is. Dit biedt kansen om opnieuw met de omgeving en bewoners te kijken naar mogelijke oplossingen. Hiertoe behoren zeker ook de lokale duurzame energievoorzieningen, waarin bewoners zelf participeren.

Ook de Omgevingswet, die hopelijk in 2021 in werking treedt, biedt nieuw instrumentarium. Daar per 2023 nieuw beleid kan worden geformuleerd, kan de Omgevingswet worden ingezet om energiebeleid in het ruimtelijk beleid te integreren. Hoewel de daadwerkelijke toepassing van de Omgevingswet zich nog moet uitwijzen, willen wij wel wijzen op de mogelijkheden die de doelstellingen en instrumenten van deze wet bieden. Omdat de inwerkingtreding wel voorzien wordt, kan alvast - zeker in combinatie met de regioplannen - worden bezien op welke wijze de instrumenten ten behoeve van de energietransitie kunnen worden ingezet. Daarbij merken wij op dat voor deze beoordeling van de kansen nog heel wat vragen en onderzoek - en dus kansen openliggen.
Het is van cruciaal belang dat het ruimtelijk beleid voor de energietransitie verder gaat dan enkel het 'inpassen' van windturbines en zonneparken in de bestaande fysieke leefomgeving ten behoeve van doelstellingen van tientallen megawatts. De energietransitie heeft niet alleen een impact op de leefomgeving, er is ook sprake van een wederzijdse invloed tussen de inrichting van de energievoorziening en de leefomgeving. Een succesvolle energietransitie is daarom afhankelijk van de manier waarop de leefomgeving (niet alleen de fysieke leefomgeving, maar ook de actoren die daarin wonen, werken en recreëren) de keuze voor verschillende transitiepaden beinvloedt. Zoals wij betoogd hebben, wordt, mede met het oog op de impact van de energietransitie op de ruimtelijke kwaliteit, idealiter op verschillende schaalniveaus gezocht naar integrale en creatieve oplossingen. Daarvoor is van belang dat de ruimtelijke afweging op lokaal niveau niet onevenredig wordt belemmerd. Wordt in de toekomst gekozen voor de grootschalige aanpak, dan zal naar verwachting een toenemend aantal conflicten ontstaan, zoals in Drenthe, Friesland en Noord-Holland. Dit is niet alleen belemmerend voor de energietransitie, maar kan ook een wig drijven tussen overheid en burgers en het maatschappelijk draagvlak voor de energietransitie. Met andere woorden: de leefomgeving is het toernooiveld van de energietransitie. 